\title{
BRIEF PROGRESS REPORTS ON HUMAN AND ENVIRONMENTAL ARCHAEOLOGICAL STUDIES OF GLACIAL LAKE AGASSIZ
}

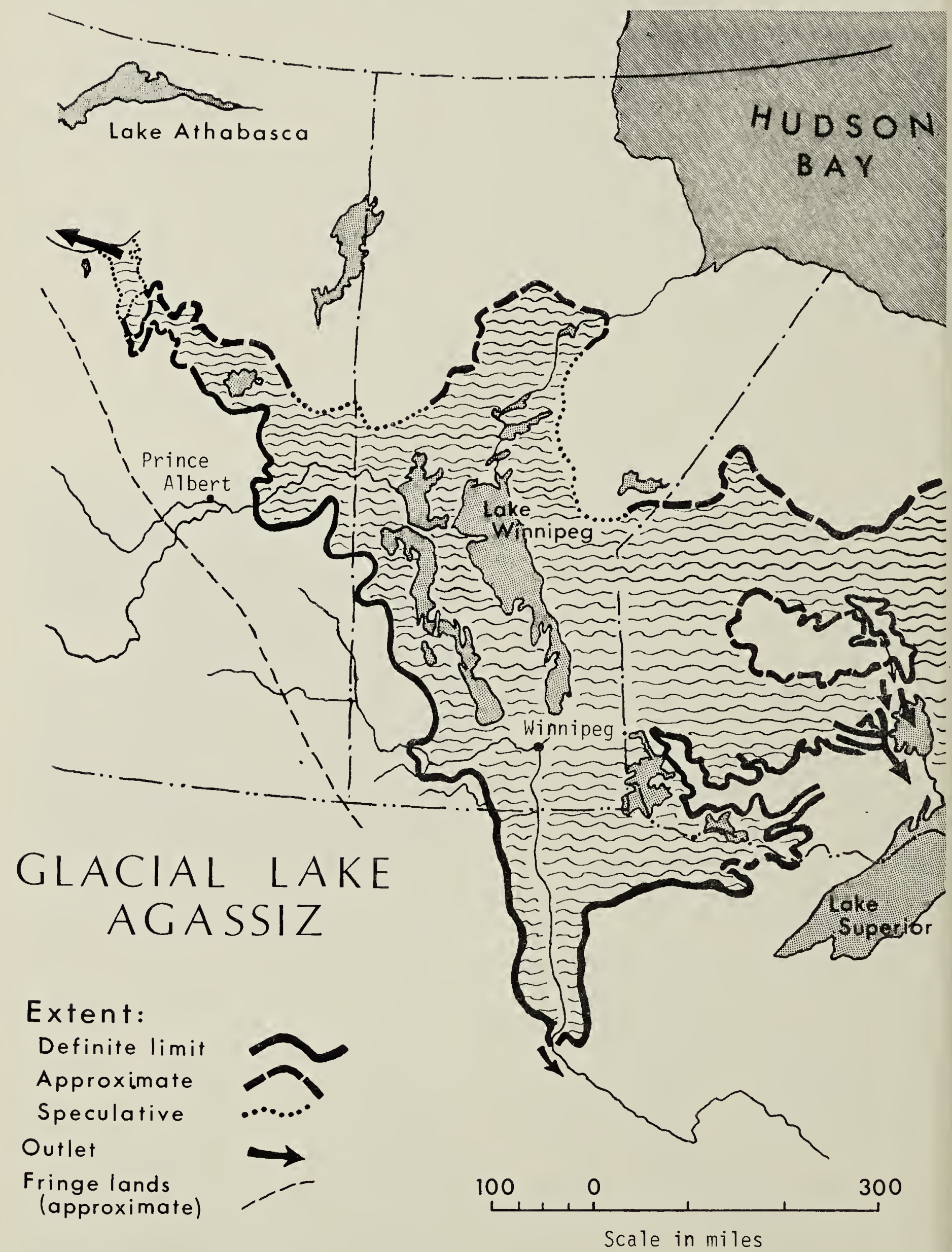

Glacial Lake Agassiz, from a geological map distributed at the Agassiz Conference in Winnipeg, November, 1966, by Dr. John Elson, McGill University, Montreal. 


\section{SASKATCHEWAN}

by Dennis E. Anderson, Field Director, and Dr. Zenon S. Pohorecky, Project Supervisor and Head, Department of Anthropology and Archaeology, University of Saskatchewan, Saskatoon

The Department of Anthropology and Archaeology, University of Saskatchewan, Saskatoon, has been busy since 1964 in an archaeological research programme involving lands affected environmentally by the largest glacial lake in the world, Glacial Lake Agassiz.

This lake began to form over 12,000 years ago, fed by waters melting from glacial ice in Saskatchewan, Manitoba and Ontario. Before draining into Hudson Bay about 6,000 years ago, it flooded the centre of North America while its outlets cut the continent in half along the Mackenzie to the Arctic Ocean and along the Mississippi to the Caribbean Sea.

Saskatchewan, too, was cut in half by a channel of Lake Agassiz which extended from the Porcupine Hills in Manitoba to the Clearwater River in Alberta. The northern borders of this channel are uncertain, but its southern margins are plotted with enough certainty to identify over 50 recession beaches and shore scarps.

The environmental study of Lake Agassiz has already involved palaeobotanists, palynologists, palaeoclimatologists, soils specialists and pleistocene geologists. Many of these natural scientisits recently met at an international conference on Lake Agassiz, sponsored by the National Research Council and held at the Laboratory of Anthropology, University of Manitoba.

Archaeological interest is focused on two zones in Saskatchewan. One follows the known margins of Lake Agassiz, and includes lands modified by waters connected with the lake. The other ("Fringe Lands") follows the outer margins of this primary zone, and includes lands influenced environmentally by the nearby lake. The project, then, encompasses almost half of Saskatchewan, and promises to rewrite the prehistory of the Canadian prairies.

Some 600 archaeological sites have already been discovered in this Agassiz area. Old campsites, butchering grounds, lithic industrial centres, flint quarries, and ancient highways have been recorded around Kamsack, Hudson Bay, Porcupine Plain, Bjorkdale, Carrot River, Tisdale, Melfort, Nipawin, Prince Albert and La Ronge.

A sequence of over 20 cultures spanning 12,000 years is now known here, and clues suggest about a dozen other cultures hitherto unidentified anywhere. This need to identify many more cultures is confirmed by numerous collectors of Indian relics in the Agassiz area, so test-excavations are being made to learn more about these unknown cultures.

The project has stimulated some historic archaeology, too. A richly supplied native historic burial had to be salvaged along the Red Deer River, and is giving insights into the furtrade of 150 years ago. A survey of Agassiz lands threatened by the Shellmouth project along the Assiniboine pinpointed the site of Fort Riviere Tremblante (1791-8), known as Cuthbert Grant's Northwest Company post, which is now being studied intensively with support from Manitoba and Saskatchewan governments.

Once considered by many as an archaeological vacuum, central Saskatchewan is proving to be a major archaeological area of North America, thanks to support by the National Research Council and the National Museum of Canada. Readers of The Blue Jay in the Agassiz area can also assist in this important programme in environmental archaeology by reporting any unusual finds to the respective Departments in Saskatchewan and Manitoba. 